\title{
Paleomagnetism of Pliocene to Pleistocene lava flows in the northern part of Hyogo prefecture, Southwest Japan and Brunhes Chron paleosecular variation in Japan
}

\author{
H. Morinaga, T. Matsumoto, Y. Okimura, and T. Matsuda
}

Laboratory of Global Tectonics, Faculty of Science, Himeji Institute of Technology, Shosha 2167, Himeji, Hyogo 671-2201, Japan

(Received December 6, 1999; Revised June 2, 2000; Accepted June 2, 2000)

\begin{abstract}
Paleomagnetic investigation was performed on 26 Potassium-Argon dated Pliocene to Pleistocene lava flows, collected at 34 sites from northern Hyogo, Southwest Japan. Most magnetic polarities were found to be coincident with the geomagnetic polarity timescale (GPTS), although two lava flows do not agree with the timescale. One of 2 lava flows incompatible with the GPTS, the Oliveine Andesite lava flow from the Oginosen volcano group dated at $0.92+/-0.05 \mathrm{Ma}$, shows normal polarity. This finding is a possible evidence confirming the existence of the Santa Rosa Event proposed recently. Twenty-two paleomagnetic data sets were used to investigate paleosecular variation (PSV) having passed the following criteria: 1) characteristic components are obtained from four specimens or more for a lava flow, 2) $\alpha_{95}$ of the lava flow mean direction is $<10^{\circ}$ and 3) the virtual geomagnetic pole (VGP) latitude calculated is $>50^{\circ}$ or $<-50^{\circ}$. The mean VGP was calculated to be latitude $=85.5^{\circ} \mathrm{N}$ and longitude $=285.3^{\circ} \mathrm{E}$ $\left(k=34.8\right.$ and $\left.\alpha_{95}=5.3^{\circ}\right)$. The resultant angular standard deviation (ASD) with respect to the geographic pole was calculated to be $14.5^{\circ}$ with the upper limit $=18.3^{\circ}$ and the lower limit $=12.1^{\circ}$. The ASD value is almost equal to most existing results from the Japan Islands. Brunhes Chron PSV in Japan was estimated using the identical criteria for selection; 66 of 87 available data sets passed. The mean VGP was calculated to be latitude $=89.3^{\circ} \mathrm{N}$ and longitude $=14.4^{\circ} \mathrm{E}\left(k=33.1\right.$ and $\left.\alpha_{95}=3.1^{\circ}\right)$. The resultant ASD with respect to the geographic pole was calculated to be $14.2^{\circ}$ with the upper limit $=16.1^{\circ}$ and the lower limit $=12.7^{\circ}$. The ASD values for the past 3 million years in northern Hyogo and for the Brunhes Chron in Japan are compatible with the global trend for the past 5 million years fitted by physical PSV Model F and phenomenological PSV Model G. This suggests that the PSV in Japan is not low compared with anomalously low PSV area in the Pacific Region.
\end{abstract}

\section{Introduction}

Most previous paleomagnetic investigations of volcanic rocks from the Japan Islands have demonstrated that angular standard deviation (ASD) of virtual geomagnetic poles (VGPs) in Japan agrees with the global trend expected from parametric or physical models of paleosecular variation (PSV) including Model C-Cox, 1962; Model D-Cox, 1970; Model F-McFadden and McElhinny, 1984. Heki (1983) reported the ASD value of $13.9^{\circ}$ for rocks younger than 40,000 years BP, collected from the Higashi-Izu monogenetic volcano group and pyroclastic flow deposits in Kagoshima prefecture. Shibuya et al. (1995) recalculated the ASD for the paleomagnetic results of Heki (1983) using a new method developed by themselves and obtained the ASD value of $15.0^{\circ}$. Tsunakawa et al. (1985) and Tsunakawa and Hamano (1988) reported the ASD values of $14.1^{\circ}$ and $13.8^{\circ}$ for the Shimokura dike swarm at $8 \mathrm{Ma}$ and Brunhes-age Ashitaka dike swarm, respectively. On the other hand, Otake et al. (1993) reported the ASD value of $12.6^{\circ}$ for Brunhes-age rocks from the Zao volcano, which is somewhat smaller than the values obtained by the other investigations mentioned above and those expected from the parametric or physical PSV models.

Copy right(C) The Society of Geomagnetism and Earth, Planetary and Space Sciences (SGEPSS); The Seismological Society of Japan; The Volcanological Society of Japan; The Geodetic Society of Japan; The Japanese Society for Planetary Sciences.
Paleomagnetic results of Quaternary volcanics, however, are not enough in number to describe the PSV in Japan. In addition, the previous works were carried out without complete magnetic cleaning or rigorous data selection to calculate the ASD.

In this paper, we 1) show paleomagnetic results for the past 3 million years for lava flows from the northern part of Hyogo Prefecture, Southwest Japan, 2) carry out a rigorous data selection process for calculation of the ASD, and 3) compare it with available results from the Japan Islands as well as the global trend for the past 5 million years fitted by the physical PSV Model F (McFadden and McElhinny, 1984) and the phenomenological PSV Model G (McFadden et al., 1988 and 1991) based upon the theoretical work of Roberts and Stix (1972). We then 4) compile all the available paleomagnetic data in the Brunhes Chron from the Japan Islands, 5) apply a rigorous data selection process and again calculate the ASD, and 6) examine consistency with the global trend expected from the Model F (McFadden and McElhinny, 1984) and the Model G (McFadden et al., 1991).

\section{Geological Setting, Paleomagnetic Sampling and Measurements}

Pliocene to Pleistocene lava flows are widely distributed in the northern part of Hyogo Prefecture. They form the composite volcanoes and more than 10 monogenetic volcanoes (Sakiyama et al., 1995). The composite volcanoes 


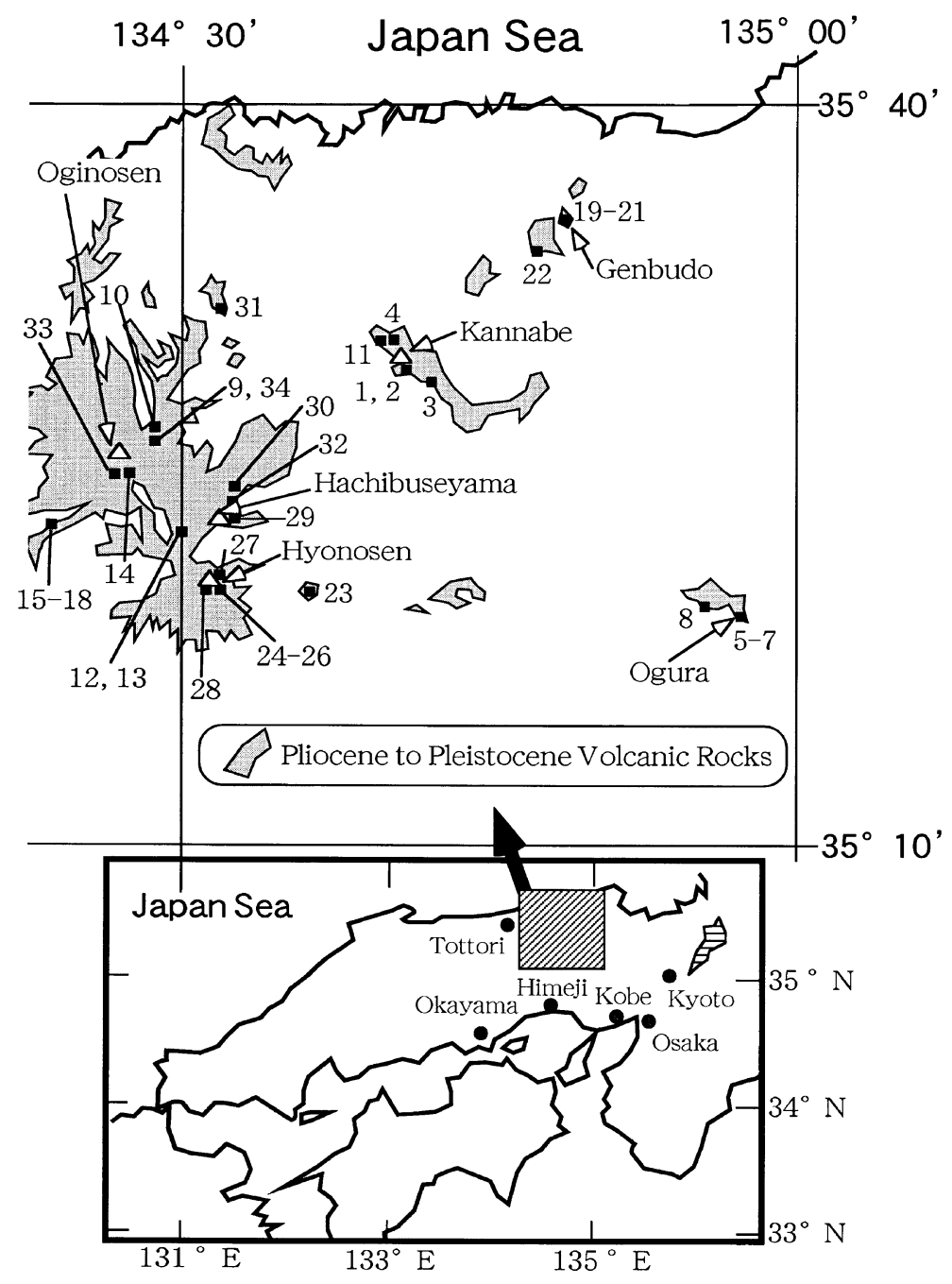

Fig. 1. Sampling localities in the northern part of Hyogo Prefecture, Southwest Japan. Gray parts represent distribution of Pliocene to Pleistocene volcanic rocks.

are Mt. Hachibuseyama, Mt. Hyonosen and Mt. Oginosen. The monogenetic volcanoes are sporadically distributed as the Kannabe monogenetic volcano group, the Takurayama, Sonae, Todoroki and Genbudo volcanoes. The K-Ar ages of the lavas investigated were reported by Furuyama et al. (1993a) and Sakiyama et al. (1995) (Table 1). We chose the lava flows younger than 3 Ma to conduct the paleomagnetic investigation. Sites of paleomagnetic sampling are listed in Table 1 and shown in Fig. 1. Collected hand samples were oriented with a magnetic compass.

The Kannabe monogenetic volcano group (KN-) includes the Nishiki, Otsukue, Buri, Tada, Kiyotaki, and Kannabe volcanoes in order of their formation (Furuyama et al., 1993a). Most rocks are olivine basalts, which were collected for paleomagnetic measurement at 5 sites of lava flows from 4 volcanoes; the Nishiki, Otsukue, Buri and Kannabe volcanoes. We collected samples from 2 sites of the youngest Kannabe volcano (1, 2 in Fig. 1). Paleomagnetic samples of the Buri, Otsukue and Nishiki volcanoes were collected from each one site (3, 4 and 11 respectively in Fig. 1).

The Takurayama volcano is formed by olivine basalt lava flows of the Ogura, Kinuzuri and Takurayama. Paleomag- netic samples were collected from 3 sites of the Ogura lava flow ( 5 to 7 in Fig. 1) and one site of the Kinuzuri lava flow (8).

The Oginosen volcano group (OG-) includes independent 19 monogenetic volcanoes and their lava flows (Furuyama et al., 1993b). Four lava flows ; the Hataganaru (9 in Fig. 1), Sugahara (10), Olivine Andesite (14) and Byobuiwa (15 to18) lava flows, were collected for paleomagnetic measurement. Their rock types are andesite, basalt, olivine andesite and basalt, respectively.

The rock type associated with the Sonae volcano is olivine basalt while that of the Todoroki volcano is alkali basalt (Sakiyama et al., 1995). Paleomagnetic samples were collected from 2 outcrops of the Sonae lava flow (12, 13 in Fig. 1) and one site of the Todoroki lava flow (23).

The Genbudo volcano is formed by two basaltic lava flows; the Genbudo lava flow and the stratigraphically overlying Akaishi lava flow (Genbudo Research Group, 1989). Paleomagnetic samples of the Genbudo lava flow were collected from 2 outcrops near the sightseeing spot (19,20 in Fig. 1) and one site located on the western side of the Maruyama River (22). The K-Ar ages of rocks from the former and latter sites are significantly different from each other; $1.53+/-0.06 \mathrm{Ma}$ 


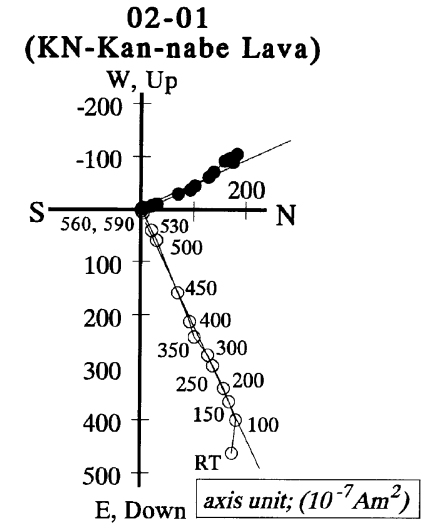

03-02 (KN-Buri Lava)

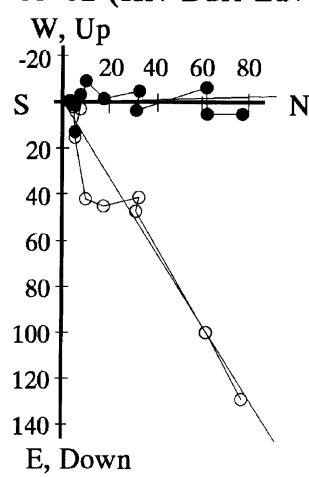

23-01
(Todoroki Lava)

14-01

(OG-Olivine Andesite Lava)

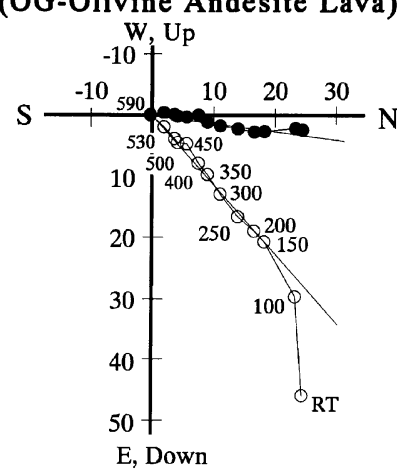

24-01 (Hyonosen Lava) $\mathrm{W}, \mathrm{Up}$

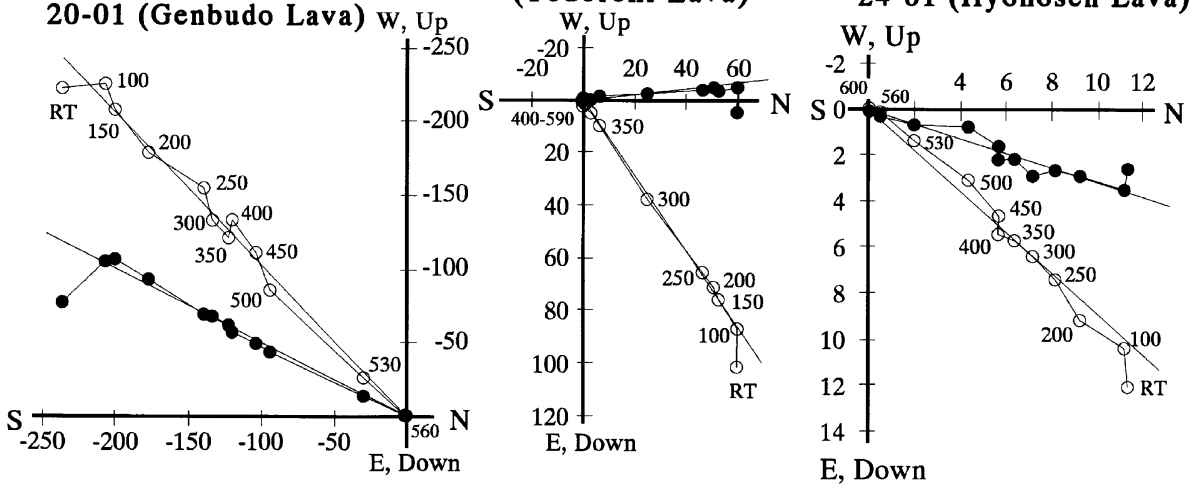

16-01

(OG-Byobuiwa Lava)

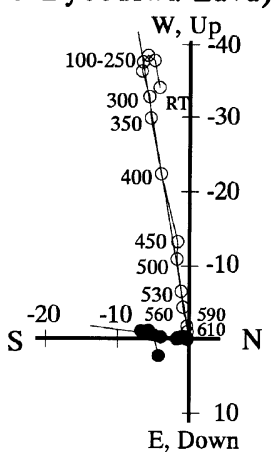

29-01

(Hachibuseyama Lava)

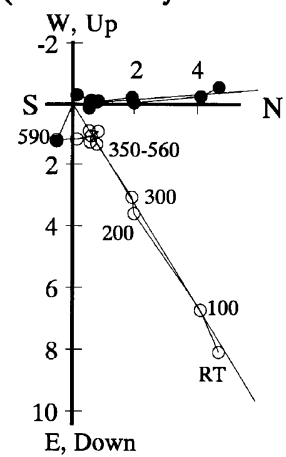

Fig. 2. Typical examples of progressive thermal demagnetization for investigated rocks.

Table 1. Summary of sampling sites and paleomagnetic results.

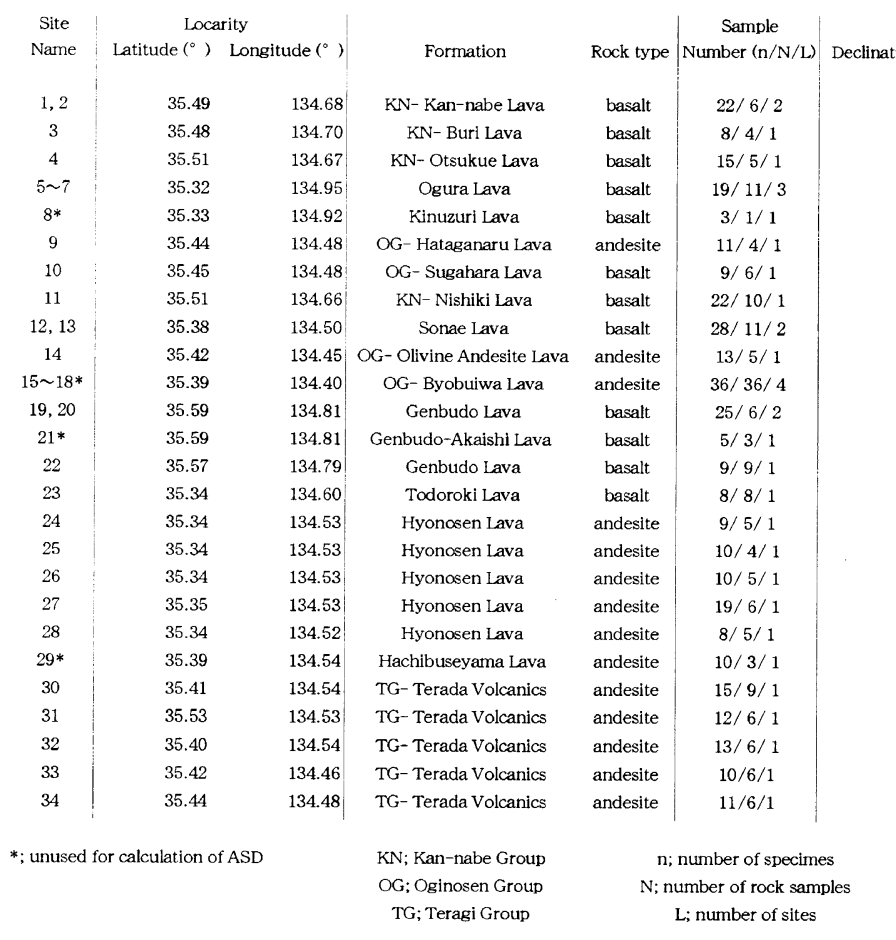

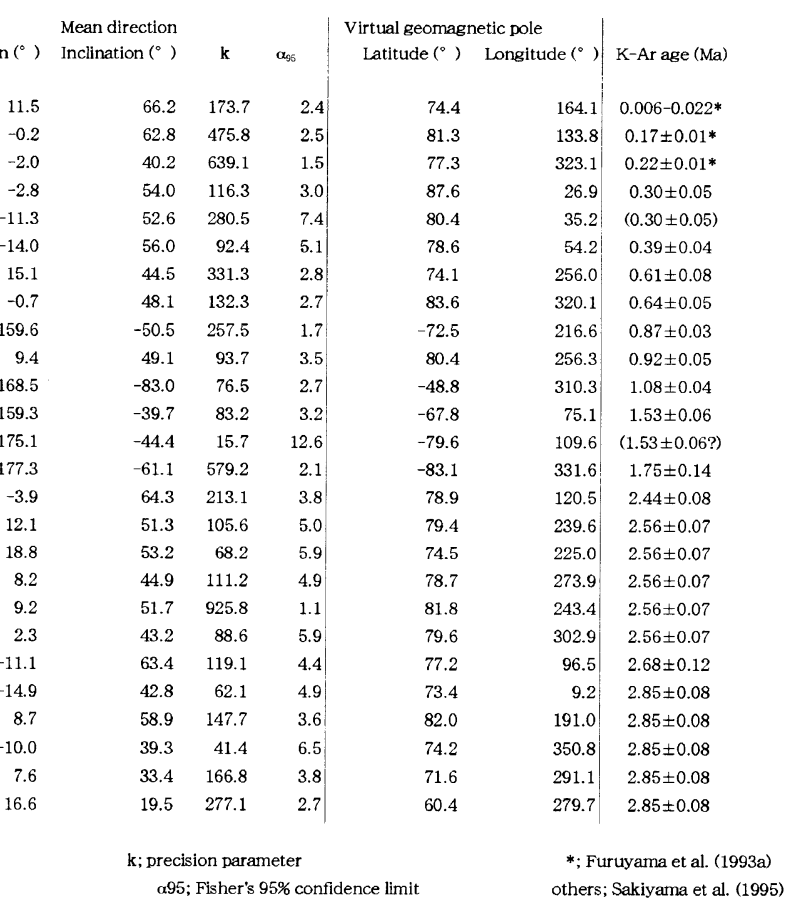

and $1.75+/-0.14 \mathrm{Ma}$ (Sakiyama et al., 1995), although the rocks of both sites seem to have been generated by simultaneous volcanic activity (Genbudo Research Group, 1991). The Akaishi lava flow samples were collected from one site (21 in Fig. 1). The K-Ar age of Akaishi lava flow is thought to be equivalent to that of the samples from the sites 19 and 20, although the lava flow is stratigraphically younger than the Genbudo lava (Genbudo Research Group, 1989). 


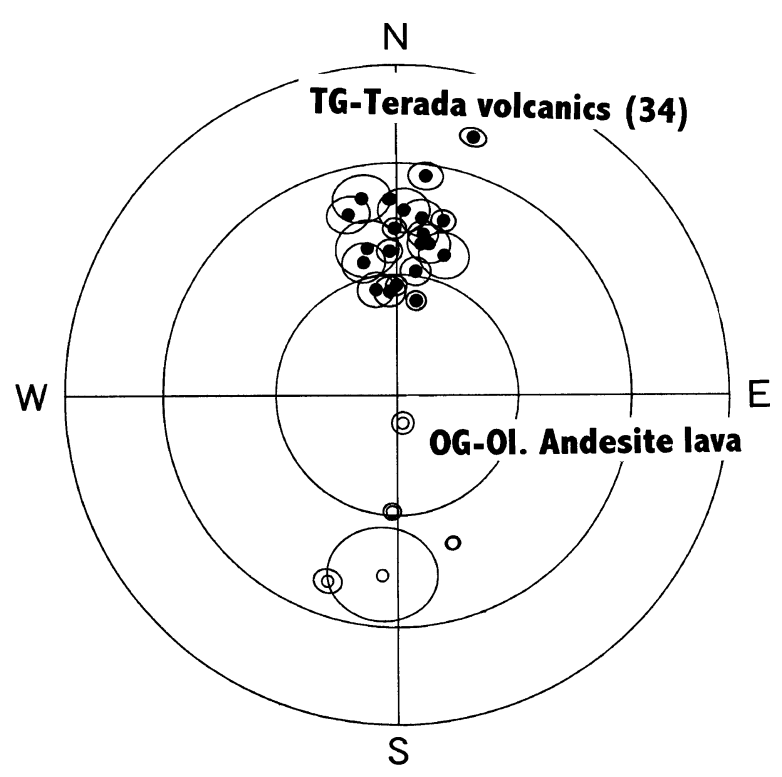

Fig. 3. Mean directions of lava flows. The values are also shown in Table 1.

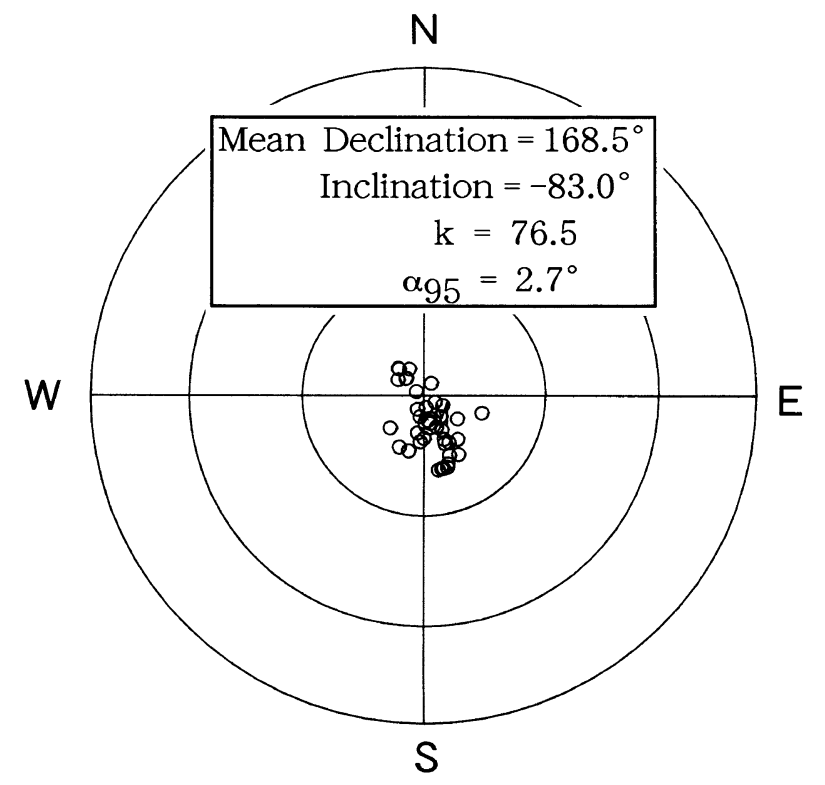

Fig. 4. ChRM directions of the OG-Byobuiwa lava specimens collected from 4 sites.

Mt. Hyonosen is a composite volcano formed by younger volcanic activity than those of Mt. Hachibuseyama and the Teragi group (Furuyama, 1989). This volcano is composed mainly of olivine-bearing pyroxene andesite, and the K-Ar ages of $2.54+/-0.06$ to $2.58+/-0.07$ Ma were obtained (Sakiyama et al., 1995). From this volcano, paleomagnetic samples were collected from 5 sites of stratigraphically independent layers (24 to 28 in Fig. 1).

Mt. Hachibuseyama is a composite volcano younger than the Teragi group and older than Mt. Hyonosen (Furuyama, 1989). This volcano is composed of mainly olivine-bearing pyroxene andesite (Sakiyama et al., 1995). From this volcano, paleomagnetic samples were collected from only one site (29 in Fig. 1).

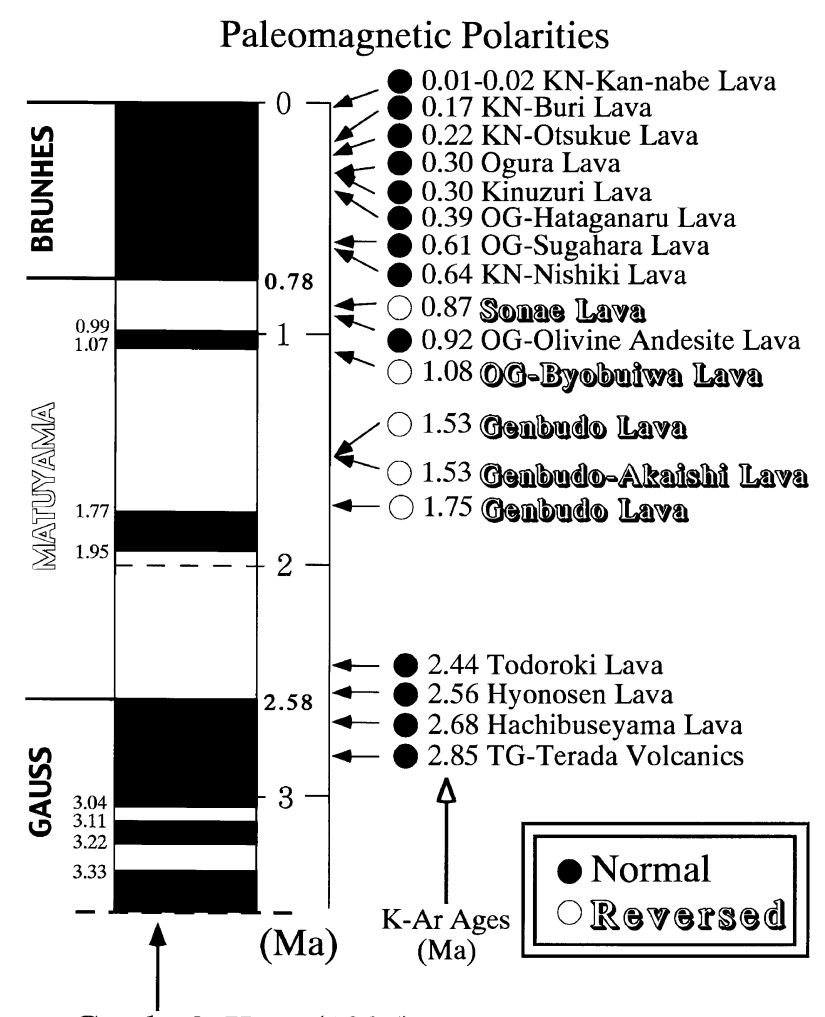

Cande \& Kent (1995)

Fig. 5. Paleomagnetic polarities of all the investigated lava flows plotted with the geomagnetic polarity timescale (Cande and Kent, 1995).

The Teragi group (TG-) is unconformably overlain by the Hachibuseyama lava flows (Furuyama, 1989). The Terada volcanics (mainly calc-alkali andesite) of the Teragi Group were collected from 5 sites ( 30 to 34 in Fig. 1).

Specimens used for magnetic measurement were $2.5 \mathrm{~cm}$ diameter cores about $2.5 \mathrm{~cm}$ long drilled from the hand samples. Remanent magnetization of the specimen was measured on a Natsuhara Giken Co. SMM-85 spinner magnetometer. Progressive thermal (Th) demagnetization was adopted to eliminate viscous remanent magnetization(VRM) and to isolate the characteristic remanent magnetization (ChRM). The specimens were generally demagnetized at twelve steps: every $50^{\circ} \mathrm{C}$ from $100^{\circ} \mathrm{C}$ to $500^{\circ} \mathrm{C}$ and every $30^{\circ} \mathrm{C}$ from $530^{\circ} \mathrm{C}$ to $590^{\circ} \mathrm{C}$ (or $600^{\circ} \mathrm{C}$ ). The ChRM component was analyzed using principal component analysis (Kirschvink, 1980).

\section{Results of Magnetic Measurements and Paleo- magnetic Interpretation}

Typical examples of the progressive Th demagnetization of the basalts and andesites are shown in Fig. 2. VRM components were eliminated at low temperature steps up to $200^{\circ} \mathrm{C}$ and afterwards only one stable component was isolated for most specimens. Some specimens (e.g. the KN-Buri lava and the Hachibuseyama lava) did not show smooth decay on horizontal and vertical components of the remanence. Only one ChRM component, however, was isolated at higher temperature steps for all the specimens. Mean ChRM direction of each lava flow is listed in Table 1 and is drawn with its 95\% confidence limit $\left(\alpha_{95}\right)$ in Fig. 3. 
The mean directions with normal polarity seem to follow a Fisherian distribution, although the direction from the site (34) of the TG-Terada volcanics slightly deviates from the overall distribution. On the other hand, the number of lava flows showing reversely magnetized data are only 5 and their mean directions are rather scattered. Most of the scatter is probably due to insufficient magnetic cleaning of secondary magnetization acquired subsequently during the normal polarity period (Brunhes Chron). The mean inclination of the OG-Byobuiwa lava is considerably steeper $\left(-83^{\circ}\right)$ than that expected from the geocentric dipole field $\left(54.5^{\circ}\right)$. Directions of all the specimens collected from 4 sites for the Byobuiwa lava flow are distributed near the pole of the upper hemisphere (Fig. 4). This steep inclination is abnormal in the Quaternary paleomagnetic direction in Japan.

The paleomagnetic polarity and the $\mathrm{K}-\mathrm{Ar}$ ages of the lava flows, excluding 3 (the OG-O1. Andesite, Todoroki and Hyonosen lava flows), show consistency with the geomagnetic polarity timescale (GPTS) reported by Cande and Kent (1995) (Fig. 5). The three exceptional lavas show normally magnetized data. Judging from the progressive Th demagnetization, they have no reversely magnetized component, indicating that they acquired the magnetization during a normal polarity period. Their K-Ar ages suggest that the Hyonosen lava flows were formed during the Matuyama reversed Chron. However, taking into consideration the error of the age determination, it is plausible that the lava flow was formed during the Gauss normal Chron. The paleomagnetic polarities of 2 lava flows (the OG-Ol. Andesite lava flow and the Todoroki lava flow) do not coincide with the GPTS, even if their age determination error is considered.

Singer et al. (1999) revised the polarity time scale to include short events precisely dated by ${ }^{40} \mathrm{Ar} /{ }^{39} \mathrm{Ar}$. These authors designated a normal event dated at $0.922+/-0.012 \mathrm{Ma}$ as the Santa Rosa Event. One of 2 lava flows incompatible with the GPTS (Cande and Kent, 1995), the OG-Ol. Andesite lava flow, shows the K-Ar age of $0.92+/-0.05 \mathrm{Ma}$ and has the magnetization of normal polarity. It is probable that this finding is an evidence confirming the existence of the Santa Rosa Event. Further investigations on the age are needed to reevaluate the possibility.

The OG-Byobuiwa lava flow shows reversely magnetized data and its polarity coincides with the GPT. The K-Ar age of the lava $(1.08+/-0.04 \mathrm{Ma})$ is almost equal to the start time of Jaramillo normal Subchron (1.07 Ma). This suggests a possibility that the steep inclination of the Byobuiwa lava flow reflects a behavior of geomagnetic field at the polarity transition.

\section{PSV for the Past Three Million Years in South- west Japan}

We selected the paleomagnetic data from this study by the following 3 criteria and calculated the ASD using the VGPs of selected data;

1) the ChRM directions are obtained from 4 specimens or more for each lava flow,

2) the statistical error angle of the mean direction $\left(\alpha_{95}\right)$ of each lava flow is less than $10^{\circ}$ (following the criterion used by McElhinny et al., 1996), and

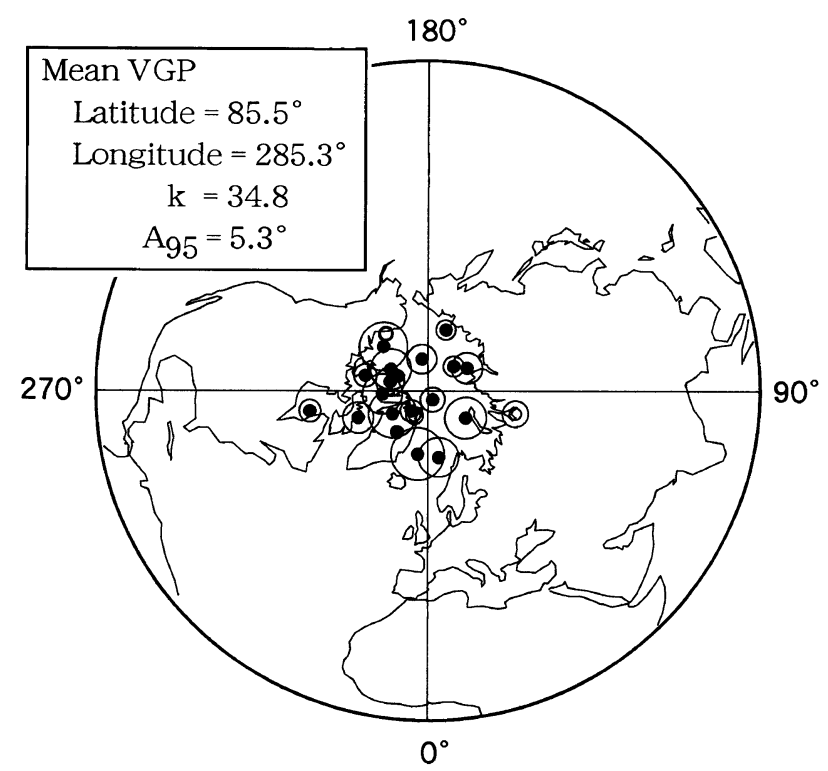

Fig. 6. Twenty-two VGP positions selected by three criteria described in the text.

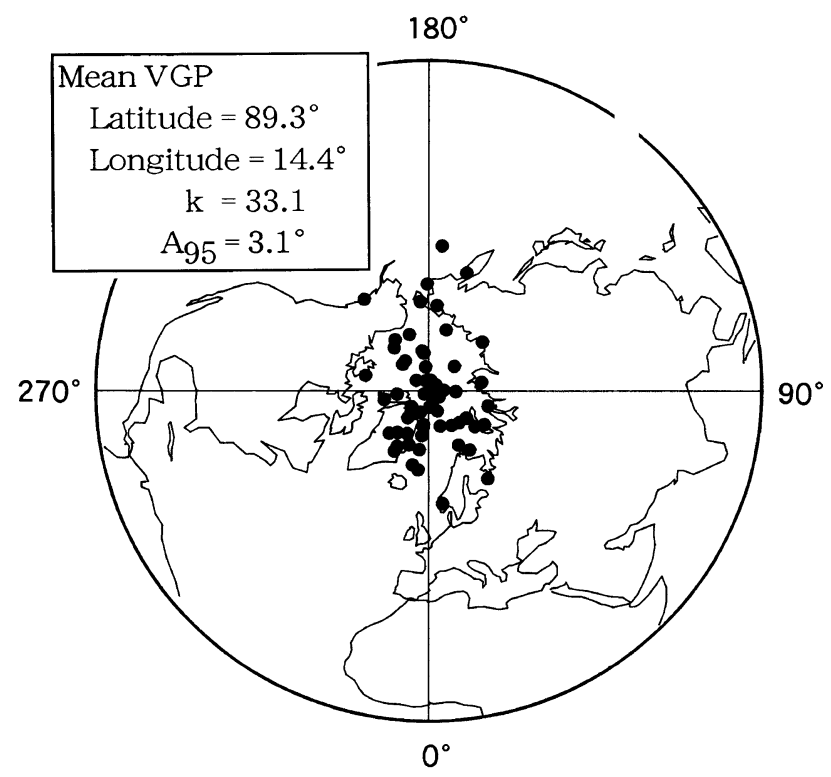

Fig. 7. Selected 66 VGPs for the Brunhes Chron from the Japan Islands.

3) the VGP latitude is more than $50^{\circ}$ or less than $-50^{\circ}$ (following the criterion used by McElhinny and Merrill, 1975).

The latter criterion effectively excludes data during polarity transitions or geomagnetic excursions.

Four lava flows were excluded by these criteria; the Kinuzuri, OG-Byobuiwa, Genbudo-Akaishi and Hachibuseyama lava flows. The mean VGP was calculated using the selected 22 VGPs (Fig. 6); latitude $=85.5^{\circ}$ and longitude $=285.3^{\circ}$ $\left(k=34.8\right.$ and $\left.\alpha_{95}=5.3^{\circ}\right)$ and the resultant ASD with respect to the geographic pole was calculated to be $14.5^{\circ}$. Its $95 \%$ confidence limit was calculated from the table presented by Cox (1969); the upper limit $=18.3^{\circ}$ and the lower limit $=12.1^{\circ}$. This ASD value is consistent with 
Table 2. Brunhes Chron paleomagnetic results of volcanic rocks in Japan.

\begin{tabular}{|c|c|c|c|c|}
\hline \multirow[b]{2}{*}{ Locality } & \multirow[b]{2}{*}{ Age } & \multicolumn{2}{|c|}{ Number of data (sites) } & \multirow[b]{2}{*}{ Reference } \\
\hline & & Published & Selected ${ }^{*}$ & \\
\hline Higashi-Izu & $<$ Late Pleistocene & 22 & 22 & Heki (1983) \\
\hline Kagoshima & $<$ about $30 \mathrm{ka}$ & 6 & 6 & Heki (1983) \\
\hline Zao & $0.10 \sim 0.36 \mathrm{Ma}$ & 11 & 9 & Otake et al. (1993) \\
\hline Ashitaka & $\begin{aligned}> & \text { several hundreds } \\
& \text { of thousand years }\end{aligned}$ & 35 & 18 & Tsunakawa and Hamano (1988) \\
\hline Goto Islands & Quaternary & 5 & 4 & Ishikawa and Tagami (1991) \\
\hline Northern Hyogo & $0.006 \sim 0.64$ & 8 & 7 & This Study \\
\hline Total & & 87 & 66 & \\
\hline \multicolumn{2}{|c|}{ *using three criteria in the text } & & & $\begin{array}{l}\text { Angular standard deviation }=14.2^{\circ} \\
\text { Its upper limit }=16.1^{\circ} \\
\text { Its lower limit }=12.7^{\circ}\end{array}$ \\
\hline
\end{tabular}

the previous results in Japan; $13.9^{\circ}$ - Heki (1983), 14.1 Tsunakawa et al. (1985), $13.8^{\circ}$ - Tsunakawa and Hamano (1988) and $15.0^{\circ}$ - Shibuya et al. (1995). This ASD value is somewhat lower yet fully compatible with the global trend for the past 5 million years fitted by the Model F (McFadden and McElhinny, 1984) and Model G (McFadden et al., 1991).

\section{Brunhes Chron PSV in Japan}

Two paleomagnetic investigations of Brunhes-age volcanics from the Japan Islands (Heki, 1983; Tsunakawa and Hamano, 1988) reported the ASD values (about $14^{\circ}$ ) consistent with the global trend predicted by parametric or physical models (Model C-Cox, 1962, Model D-Cox, 1970, and Model F-McFadden and McElhinny, 1984). On the other hand, Otake et al. (1993) reported slightly smaller ASD value of $12.6^{\circ}$, from the paleomagnetic investigation of 11 lavas and dikes dated as 0.10 to $0.36 \mathrm{Ma}$. Ishikawa and Tagami (1991) also reported 5 paleomagnetic data sets referred to as Quaternary basalts from the Goto Islands, whose polarities are all normal, suggesting that they were formed during the Brunhes Chron. Therefore, their VGPs are useful to calculate the ASD for the Brunhes Chron.

We calculated the Brunhes Chron ASD in Japan using the paleomagnetic results from 4 previous investigations mentioned above and the present study. Sixty-six directional data (Fig. 7) were selected from a total 87 data available by the three criteria of data selection used above (Table 2 ). The mean VGP was then calculated; latitude $=89.3^{\circ}$ and longitude $=14.4^{\circ}\left(k=33.1\right.$ and $\left.\alpha_{95}=3.1^{\circ}\right)$. The ASD with respect to the geographic pole is calculated to be $14.2^{\circ}$ with its upper limit $=16.1^{\circ}$ and the lower limit $=12.7^{\circ}$.

The resultant ASD value is almost equal to the value $\left(15.0^{\circ}\right)$ calculated by the least square fitting to the cumulative distribution of Brunhes-age VGP data from the Japan Islands (Shibuya et al., 1995). This ASD value is also compatible with the global trend for the past 5 million years expected from the Model F (McFadden and McElhinny, 1984) and Model G (McFadden et al., 1991). Shibuya et al. (1995) documented that the PSV in Japan is not low compared with anomalously low PSV area in the Pacific Region (Doell and Cox, 1972). Our investigation again draws the same conclusion.

\section{Conclusions}

Twenty-three of the 26 Pliocene to Pleistocene lava flows from the northern part of Hyogo Prefecture show magnetic polarities coincident with the GPTS (Cande and Kent, 1995). Two lava flows do not agree with the GPTS, even if the error of age determination is considered. One of the two lava flows, the OG-Ol. Andesite lava flow dated at $0.92+/-0.05 \mathrm{Ma}$, shows normally magnetized data. This finding is a possible evidence confirming the existence of the Santa Rosa Event (Singer et al., 1999).

We used three criteria for the data selection in order to calculate the ASD. The ASD value of VGPs for the past 3 million years $\left(14.5^{\circ}\right)$ was obtained from 22 paleomagnetic data selected by the criteria. Its $95 \%$ confidence limit was calculated to be the upper limit $=18.3^{\circ}$ and the lower limit $=$ $12.1^{\circ}$. This value is consistent with the previous results from the Japan Islands and is also compatible with the global trend for the past 5 million years fitted by the Model F (McFadden and McElhinny, 1984) and Model G (McFadden et al., 1991).

Using the available paleomagnetic data of the Brunhes-age volcanic rocks from the Japan Islands and the three criteria for the data selection, 66 useful VGPs were obtained from 87 data available. The ASD of the VGPs for the Brunhes Chron was calculated to be $14.2^{\circ}$ with its upper limit $=16.1^{\circ}$ and the lower limit $=12.7^{\circ}$. In Japan a characteristics of PSV during the Brunhes Chron were fully compatible with the global trend expected from the Model F (McFadden and McElhinny, 1984) and Model G (McFadden et al., 1991). Our result again demonstrates that the PSV in Japan is not low compared with anomalously low PSV area in the Pacific Region (Shibuya et al., 1995).

Acknowledgments. We thank greatly two reviewers, Prof. M. Kono of Okayama University and Prof. K. A. Hoffman of California 
Polytechnic State University, for valuable comments and helpful suggestions. This investigation was supported by the project for collection of natural environmental information, carried out from 1991 to 1993 by Museum of Natural and Human Activities of Hyogo Prefecture, Japan.

\section{References}

Cande, S. C. and D. V. Kent, Revised calibration of the geomagnetic polarity timescale for the Late Cretaceous and Cenozoic, J. Geophys. Res., 100 6093-6095, 1995.

Cox, A., Analysis of present geomagnetic field for comparison with paleomagnetic results, J. Geomag. Geoelectr., 8, 101-112, 1962.

Cox, A., Confidence limits for the precision parameter $\kappa$, Geophys. J. R. astr. Soc., 18, 545-549, 1969.

Cox, A., Latitude dependence of the angular dispersion of the geomagnetic field, Geophys. J. R. astr. Soc., 20, 253-269, 1970.

Doell, R. R. and A. Cox, The pacific geomagnetic secular variation anomaly and the question of lateral uniformity in the lower mantle, The Nature of the Solid Earth, pp. 245-285, McGraw-Hill, New York, 1972.

Furuyama, K., Geology of the Teragi Group, Southwest Japan —with special reference to the Terada Volcanics-, J. Geosci. Osaka City Univ., 32, 123-173, 1989.

Furuyama, K., K. Nagao, K. Kasatani, and S. Mitsui, K-Ar ages of the Kannabe Volcano Group and the adjacent basaltic monogenetic volcanoes, east San-in district, Earth Science (Chikyuu Kagaku), 47, 377-390, 1993a (in Japanese with English abstract).

Furuyama, K., K. Nagao, S. Mitsui, and K. Kasatani, K-Ar ages of Late Neogene monogenetic volcanoes in the east San-in district, Southwest Japan, Earth Science (Chikyuu Kagaku), 47, 519-532, 1993b.

Genbudo Research Group, High-P and low-Si and -K Quaternary lava from Genbudo, northern Kinki district, Japan, Earth Science (Chikyuu Kagaku), 43, 231-236, 1989.

Genbudo Research Group, Geology and petrology of Quaternary volcanic rocks from the Genbudo area, northern Hyogo Prefecture, southwest Japan_-Genbudo and Akaishi lavas_- Earth Science (Chikyuu Kagaku), 45, 131-144, 1991 (in Japanese with English abstract).

Heki, K., Paleomagnetic study of the Higashi-Izu monogenetic volcano group and pyroclastic flow deposits in Kagoshima Prefecture: Paleosecular variation during the last 40,000 years in Japan, J. Geomag. Geoelectr., 35, 383-390, 1983.

Ishikawa, N. and T. Tagami, Paleomagnetism and fission-track geochronology on the Goto and Tsushima Islands in the Tsushima strait area: Im- plications for the opening mode of the Japan Sea, J. Geomag. Geoelectr., 43, 229-253, 1991.

Kirschvink, J., The least-squares line and plane and the analysis of palaeomagnetic data, Geophys. J. R. astr. Soc., 62, 699-718, 1980.

McElhinny, M. W. and R. T. Merrill, Geomagnetic secular variation over the past 5 my, Rev. Geophys. Space Phys., 13, 687-708, 1975.

McElhinny, M. W., P. L. McFadden, and R. T. Merrill, The myth of the Pacific dipole window, Earth Planet. Sci. Lett., 143, 13-22, 1996.

McFadden, P. L. and M. W. McElhinny, A physical model for palaeosecular variation, Geophys. J. R. astr. Soc., 78, 809-823, 1984.

McFadden, P. L., R. T. Merrill, and M. W. McElhinny, Dipole/quadrupole family modeling of paleosecular variation, J. Geophys. Res., 93, 11,58311,588, 1988.

McFadden, P. L., R. T. Merrill, M. W. McElhinny, and S. Lee, Reversals of the Earth's magnetic field and temporal variations of the dynamo families, J. Geophys. Res., 96, 3923-3933, 1991.

Otake, H., H. Tanaka, M. Kono, and K. Saito, Paleomagnetic study of Pleistocene lavas and dikes of the Zao Volcano Group, J. Geomag. Geoelectr. 45, 595-612, 1993.

Roberts, P. H. and M. Stix, a-effect dynamos by the Bullard-Gellman formalism, Astron. Astrophys., 18, 453-466, 1972.

Sakiyama, T., T. Matsuda, H. Morinaga, A. Goto, and S. Kato, Pliocene to Pleistocene volcanic rocks in northern Hyogo Prefecture, Southwest Japan-K-Ar age, paleomagnetism and major elements-, Humans and Nature, 6, 149-170, 1995 (in Japanese with English abstract).

Shibuya, H., J. Cassidy, I. E. M. Smith, and T. Itaya, Paleomagnetism of young New Zealand basalts and longitudinal distribution of paleosecular variation, J. Geomag. Geoelectr., 47, 1011-1022, 1995.

Singer, B. S., K. A. Hoffman, A. Chauvin, R. S. Coe, and M. S. Pringle, Dating transitional magnetized lavas of the late Matuyama Chron: Toward a new ${ }^{40} \mathrm{Ar} /{ }^{39} \mathrm{Ar}$ timescale of reversals and events, J. Geophys. Res., 104, 679-693, 1999.

Tsunakawa, H. and Y. Hamano, Paleomagnetic study of the Ashitaka dike swarm in Central Japan, J. Geomag. Geoelectr., 40, 221-226, 1988.

Tsunakawa, H., K. Heki, and K. Amano, Paleomagnetism of the Shimokura dike swarm in Northeast Japan, J. Geomag. Geoelectr., 37, 979-985, 1985 .

H. Morinaga (e-mail: magnet@sci.himeji-tech.ac.jp), T. Matsumoto, Y. Okimura, and T. Matsuda 